\title{
Human Rights and Eastern Orthodox Understanding and Teachings for a Troubled World
}

\author{
Joseph Mensah Onumah \\ Department of Accounting \\ University of Ghana Business School \\ College of Humanities \\ University of Ghana, Legon \\ www.ug.edu.gh \\ Angelo Nicolaides \\ Department of Philosophy and Applied Ethics \\ Faculty of Arts, University of Zululand Kwa-Dlangezwa, South Africa \\ University of Zululand, South Africa \\ http//:orcid.org/0000-0002-2153-2853
}

DOI:10.46222/pharosjot.1029

\begin{abstract}
A discourse of human rights applies to the relations between individuals and relations between them and the state. However, from an Eastern Orthodox perspective, Biblical law diverges, and applies to even the responsibilities of entities towards themselves and their responsibilities towards God the Creator. There is a seemingly increasing declaration that human rights standards are being kept, but it is also apparent that the issue has been wavering globally for numerous years. It is clear that the COVID-19 pandemic has accelerated the destruction of the democratic fabric of the social order on which the defence of human rights is finally contingent. The question this article seeks to answer is what is the understanding of the Eastern Orthodox faith when it comes to human rights issues and what is the Church in general doing to assist in mitigating these? What is the relationship between Orthodoxy and human rights and what part does it play in the advancement of human rights? How can Orthodox teachings contribute to the protection of the dignity of the individual? The concept of ethics and human rights are positive formulations, the two seen as quality features of the Universal Creator, with ethics being the relevant catalyst to human rights and relations. Human rights are therefore expected to shape the living of man as ethics motivates human performance.
\end{abstract}

Keywords: Eastern Orthodox Church, ethics, human rights, dignity, Imago Dei, Christocentric life.

\section{Introduction}

In the last decade in which secularization and rampant materialism have soared, human rights issues have increasingly gained ground and the teachings of all faith-based institutions and how humanitarian issues are approached from a faith perspective are more under the microscope' (Yang, 2016). This has been exacerbated by the global Covid-19 pandemic which is sweeping through the world. There is consequently a growing sense of urgency relating to a multiplicity of human rights issues including inter-alia soaring global poverty, unemployment, social injustices, racism, crime, corruption, a lack of impartiality, environmental degradation, non-sustainable development and others. The global population of roughly 7.5 billion people is being sorely tested and challenges abound for all religious faiths, and in this context, Christian churches are under immense pressure to support governments and the people in countries in which they operate. 
Religion per se, is increasingly becoming a component of political life that cannot be disregarded. Christianity, for one, has a huge impact on political life and raises countless deliberations. What role should Easter Orthodox Christianity (Orthodox) play in domestic and international politics or should the Church be deprived of any political role? There is a growing "secularization and sanctification of humanitarianism" (Barnett \& Stein, 2012) in the world in which we live. There is seemingly an increasing assurance that human rights standards are being kept, but it is also evident that the issue has been vacillating globally for numerous years. It is clear that the COVID-19 pandemic has quickened the destruction of the democratic fabric of the social order on which the defence of human rights is finally contingent. Numerous governments now have the perfect excuse to exploit fears and crack-down on dissent, and they are restricting people's rights and tend to pass emergency legislation that risks having long-term consequences, beyond the health crisis. The direction taken will inevitably profile the type of society we want to live in and impart to future generations (Mijatović, 2020). The question this article seeks to answer is what is the understanding of the Eastern Orthodox faith when it comes to human rights issues and what is the Church in general doing to assist? What is the relationship between Orthodoxy and human rights and what part does it play in the advancement of human rights? How can Orthodox teachings contribute to the protection of the dignity of the individual?

The research methodology employed in this study was twofold, namely historical-grammatical exegesis in which the researcher has endeavoured to interpret any passage according to the natural sense of the words or 'grammatical' aspects and according to the probable historical meaning of the author in his or her own time. This is thus a Christian hermeneutical method that strives to discover the biblical authors' original intended meaning in a text (Elwell, 1984). The Orthodox Church principally engages in a spiritual, allegorizing hermeneutic which is deeply dependent on typological connections drawn by New Testament writers and the Early Church Fathers who were significant Christian theologians and writers who established the intellectual and doctrinal foundations of global Christianity during the first several centuries of Christianity (Stylianopoulos, 2008). The Early Church fathers lived in the 1st and 2nd centuries $\mathrm{CE}$, and are held to have personally known some of the Twelve Apostles, and where pointedly influenced by them (Peterson, 1913). Orthodox doctrine is generally determined by the consensus of the Holy Fathers and the issues on which they agree. This compromise guides the church in the questions of its dogma, the correct interpretation of holy scripture, and in distinguishing the authentic holy tradition of the Church from false teachings that abound (Pomazansky, 1984).

Consequently, a literature review was conducted of relevant books, academic articles, and other sources germane to the human-rights issue and Orthodoxy. The authors thus searched for relevant Eastern Orthodox and other literature, evaluated the sources, and identified themes, debates and gaps, and then described, summarised and offered a critical evaluation of the material in relation to the research problem investigated.

\section{Human Rights today}

The Universal Declaration of Human Rights (UDHR) was indeed a landmark document in the pursuit of human rights. It was drafted by representatives from diverse legal and cultural backgrounds and was proclaimed by the United Nations General Assembly in Paris on 10 December 1948 (General Assembly resolution 217 A). It was considered to be a mutual standard of achievements for all peoples and all nations. It set out, for the first time, fundamental human rights which need to be universally protected. It states in its preamble: "Whereas recognition of the inherent dignity and of the equal and inalienable rights of all members of the human family is the foundation of freedom, justice, and peace in the world." All human beings are considered having been born free and equal in dignity and rights. Their rights, include inter-alia, the right to life and freedom, freedom of conscience and religion, abolition of any forms of slavery and human trafficking, free choice of employment, right to 
education, right to health care and many others. Despite these rights being drafted into laws, people are often denied them.

Notwithstanding various tensions in the ecumenical movement such as doctrinal issues ".the common faith" lives on today and human rights are in need of support (Moltmann, 1979). Most churches believe that people who are downtrodden and devoid of human rights and freedom, must be supported in terms of becoming part of a community of equals, in which the church supports them and where human rights are practiced and thus a "...counter-hegemonic human rights approach" is required (Palm, 2016). Those who are helpless require immense support in an approach to bolster their human rights and circumvent co-optation to serve existing powers (se Sousa Santos in Palm, 2018).

The human rights discourse is a secular indicator of Eastern Orthodox morality. It is globally the case that Christian church teachings and Christian principles are imperative for a vigorous democratic society and for a humanitarian world that values the notion of human rights and social diversity. In this regard, Orthodoxy and other Christian denominations and their range of ideas can endorse true democracy and promote human rights by playing a dynamic part in civil society.

It was in the Old Testament that the Israelites delivered the moral regime which is currently taken for granted. Moyn's Christian Human Rights narrates how after World War II, Orthodox, Catholic, and also Protestant theorists conceived of the modern human rights movement. The Roman Catholic Church and some Protestant churches dominated the debate of the new principles of human rights and Moyn contends that human dignity became a central issue to the Christian political discourse from 1937. Moyn concluded that no person attentive to where human rights emanated from can afford to disregard Christianity (Carletta, 2016).

At first glance, it seems that there are major differences between the weltanschauung of the Holy Bible and that of modern human rights but this is however a flawed perspective. The Holy Scriptures are basically theocentric and the discourse of human rights is highly anthropocentric. The Holy Bible does not consider law to be the product of dynamic human choice, but it is rather a divine imposition that people are commanded to submissively adhere to in a responsible fashion by God and thus it is theocentric (Exodus $24: 7$ ). In the anthropocentric view, human rights emphasises the unrestricted self-directed individual adhering to a social contract in which ultimate authority moves from the individual, who willingly surrenders autonomy in order to realize security (Traer, 1988).

The rights pronounced in the Universal Declaration of Human Rights also tried to launch the association between the individual and the state and protect human dignity. Human rights are generally associated with liberalism which reveals its belief in the inherent worth of all human beings and its rebuttal to sacrifice some individuals for the advancement of society (Rawls 1971). John Rawls characterizes principles of justice as having originated in somewhat of a social contract. Rawls tells us, "Each person possesses an inviolability founded on justice that even the welfare of the society as a whole cannot override" (Rawls, 1971). This informs that we make cogent, collective choices and enforce morals by agreement. This is however based upon a moral, political and economic theory. Rawls also says "...society is a more or less selfsufficient association of persons who in their relations to one another recognize certain rules of conduct as binding and who for the most part act in accordance with them...these rules specify a system of cooperation designed to advance the good of those taking part in it" (Scanlon, 1975). Rawls accepts an ideal of people as moral persons who regard themselves as being free and equal, and have a conception of their rational good as well as a sense of justice, but yet many millions are treated inhumanely by others on a daily basis. There are also people including Christians who use religious arguments in the broader society to eloquently state that people are good and there is a "moral link between people who have the law of God in scripture and those who have it inscribed on their hearts" (Lovin, 1989). There are however "rights" and "obligations" in Christianity such as the commandment "Thou shalt 
not steal" (Exodus 20 : 15) which suggests one has a right to property. Correspondingly, "Thou shalt not kill" (Exodus $20: 13$ ) infers a right to life. Scripture uses the language of obligation because it expresses a religious consciousness.

The political ideology of Liberalism that currently pervades society includes some essential interpretations. People are considered to be free and equal members of a society and there must be dignity for all persons. All should be able to be equal and assert their rights against the government. Every person then has certain inalienable rights that no government should encroach upon. Where people do not share in human rights equally, the rights do not really exist. Many countries today continue to backtrack on human rights issues. Human rights is under duress today as the phantasmagoria of international politics is fluctuating, and there is a growing ascendancy of "...domination, nationalism, and walled-in sovereignty..." (UNO Human Rights High Commissioner, 2017). Human-created human rights violations are completely within reach if a Christian or other religious ethos can truly pervade the world. Sadly however, world leaders caught up in materialism and increasing secularization appear progressively to be whirling away from multilateral institutions, making it virtually impossible to offer meaningful solutions to global human rights issues. There is thus a growing realisation that the human rights discussion has come to constitute a significant point of engagement for the Christian churches in general failing which the desired equal dignity and worth of individuals and the protection of their individual freedoms will not be realised. Moyn believes that Christian theorists who conceived of the modern human rights discourse were not as much interested in Enlightenment-inspired efforts to unshackle people but more attentive to limiting the power of the state to allow one to enjoy a meaningful spiritual existence (Carletta, 2016).

While many have become free from tyranny and poverty and are seemingly free to live the lives they want, many have sadly not benefited in the same way and continue to be inhumanely treated. Societies have generally believed that human rights violations are purely superficial cracks in what is otherwise a 'solid edifice'. However, the Covid-19 pandemic has destroyed that impression and the pandemic has hugely magnified all prevailing inequalities in the world and has aggravated many of them. People were not equal before the pandemic, and are not equal in the face of it either. Those who were poor before are now poorer than ever and the disadvantaged now face even greater disadvantages (Mijatović, 2020). The human rights movement faces a hazardous future. The multilateral, rules-based system is now severely under attack, "...the climate crisis is at the point of no return, and the future of work itself is in a state of profound change" (Institute for Human Rights and Business, 2020). The world is now on the verge of a moral bankruptcy and in need of deeper sincere spirituality in which there is an ethic of care for the other. Contemporary institutions have besmirched our social practices and a new vision of societies and practices is needed. It is through various faiths that people are fashioned in the virtues desired to create and preserve just institutions, and it is here that Orthodox Christians and others should provide a Christocentric vision and set the desired case.

\section{Ethical Dimension of Human Rights}

Ethics (attitude to life) and human rights (almost freedom to choose and act) are variables that emanated from God to human beings. These two concepts can be seen as very prominent part of the universally expected way of life, which God prescribed for His creation. One can see it as even an aspect of the general living and action of the Creator (Himself), hence even existing before man's creation. Linked with Christendom, the bible says: "... So God created the great creatures of the sea ... And God saw that it was good. God blessed them and said, 'Be fruitful and increase in number and fill the water in the seas, and let the birds increase on the earth." (Genesis 1:21, 22). The concept of being fruitful pronounced by God is a symbol of ethics, of positive attitude which the Creator infused into creation. Hence as an engrained 
feature of man, ethics has to do with general human behaviour, which is expected to be a normal way of thought and subsequent action.

Ethics is seen as an old concept evolving from the two ancient Greek scholars - Socrates and Aristotle (Svensson \& Wood, 2003) - originating from the Greek word 'ethos' meaning 'character' or 'custom'. Baker (2014) considers the word as how an individual sees himself/herself as a moral being/matter relating with other(s) or generally in society. In a more refined way, the case has been made that ethics has involved seeking for what is good, doing such good and having the commitment to what is generally accepted as right in society (Duska, Duska \& Ragatz, 2011).

The concept of ethics appears to be rooted not only in the morals of society but also in the core values of individuals depending on the environment of the person (Sims \& Felton, 2006; Hall, 2011). The word is also seen as a synonym for morals, morality, moral principles of conduct and issues of belief of what can be right and wrong (Peursem \& Julian, 2006). The traditional society is considered to be existing on such a nature of virtue and trust having persisted through the centuries, and achieved desired outcomes. Hall's (2011) assertion has been that ethics is a function of both culture and time, the time concept bringing up the position that ethics might change over time, to meet the dynamics of particular time(s). Ethics has been concerned with doing what is considered to be right and generally acceptable in society.

Linking this practically with accounting, the accounting profession has been seen as having public trust and confidence because of the profession's compliance with ethical standards (Smith, 2003). And educationally and in business, and professionally, Callahan and Bok (2012) mention that the concept of ethics has been incorporated in higher education for a long time, but the current stress coming up especially in business education and professional accounting practice as a result of the corporate scandals witnessed at the beginning of the $20^{\text {th }}$ century hence the collapse of some well-known firms. Adding to confirm to the dearth of such ethical behaviour of accountants (until recent reforms), Simpson, Onumah and OppongNkrumah (2015) observed in a study that accountants were considered to have failed earlier and often in their ethical behaviours, hence practices because of the limitation of such ethical concept in accounting syllabus and programmes

Therefore, the concept of ethics has a linkage with human rights, based on the position that human right in another way is seen to be an appropriate interactive concept that expects positive behavioural model from individuals in any form of society. In any economy, therefore, the general interaction of the citizens is based on the fact that ethics is seen to be the driving force of positive thought and subsequent resulting action(s), which therefore expects all citizens to put forward ethical and standardised way of living. Again, all the universally identified variables of human rights, therefore, have intrinsic issues of ethics (the origin being God), hence having the positive expectation of way of life, generally, that will be devoid of intentional problems and anxieties.

The modern paradigm of human right in another way has varying dimensions. This is meant to meet the general complexity of the modern human race created to address the multiplicity of current developments and structures, all in the attempt "to reach possibly the peace that passes all understanding". The modified version of current human right has been the creation of man resulting from complexities developed into systems and structures hence impeding the smooth achievement of objectives through human, government, national, international, etc efforts.

In additional way to the discourse made earlier in the paper, the international dimension of human right can be seen through the extended explanation of the concept as documented by United Nations: "Human rights are rights inherent to all human beings, regardless of race, 
sex, nationality, ethnicity, language, religion, or any other status. Human rights include the right to life and liberty, freedom from slavery and torture, freedom of opinion and expression, the right to work and education, and many more. Everyone is entitled to these rights, without discrimination."

\title{
Universal Declaration of Human Rights
}

A beginning brief of the Declaration states that it:

\begin{abstract}
...is a milestone document in the history of human rights. Drafted by representatives with different legal and cultural backgrounds from all regions of the world, the Declaration was proclaimed by the United Nations General Assembly in Paris on 10 December 1948 by General Assembly resolution 217 A (III) as a common standard of achievements for all peoples and all nations. It sets out, for the first time, fundamental human rights to be universally protected. Since its adoption in 1948, the UDHR has been translated into more than 500 languages - the most translated document in the world - and has inspired the constitutions of many newly independent States and many new democracies. (United Nations)
\end{abstract}

Further detailed extensions and reviews of such human rights are seen in this paper through important theories and discussions on human right with accompanying processes and structures in the following sections.

\section{The Eastern Orthodox View on Human Rights}

Christians generally concur that all pronouncements about human rights begin with faith in God, who essentially transcends creation and yet exists within it. Human rights are identified through reason as well as God's revelation to humanity.

Orthodox Christians are "integral to the ethical and operational complexities of globalized humanitarianism. As a historical matter, the Orthodox Church has taken seriously its biblical commission to act as a transformative agent in the world, and the record of the Orthodox Church is replete with original, creative, and sustained activities that fit neatly within the intersecting social science and policymaking taxonomies of humanitarianism, human security, and development" (Prodromou \& Symeonides, 2016). The Church maintains that human rights can in no way be superior to the spiritual world and human rights should be subject to God's will and thus final authority rests with the Creator (Trostyanskiy, 2010). In the Holy Bible, God concentrates on human responsibilities and duties and people are accountable to apply justice and extend compassion (Micah 6:8). Thus, if all people do what God wishes, human rights would not be a problem. All would receive what they need through God's grace. In the early New Testament instruction of the Church, the concept of human self-esteem is implied. Christ's gift is the fullness of life (John 10:10). Paul tells us that "...for freedom Christ has set us free," and we do not need to live as slaves (Galatians 5:1).

People were and are created in the Imago Dei of God (Genesis $1: 27$ ) and consequently all human beings thus inherently possess a facet of the Divine and consequently have categorical personal worth. We read: "So God created man in his own image, in the image of God he created him; male and female he created them" (Micah 6:8). Proverbs 31:8-9 teaches us: "Open your mouth for the mute, for the rights of all who are destitute. Open your mouth, judge righteously, defend the rights of the poor and needy". However, the Orthodox church, for example, says abortion and homosexuality cannot be defended as constituting basic rights. "Such issues are seen as a product of the Western notion of human rights, which church representatives argue does not apply to Russia and should be replaced by Orthodox principles"(Siskova, 2008). 
The Eastern Orthodox Church locates human rights in God alone as the source of moral good, recognising the true nature and dignity of humankind to be revealed in the Trinity. In communion with the triune God, each person attains an understanding of his/her true humanity. In relationship with others we, in turn, recognise the dignity of humanity that is created in the image of the Godhead. For Orthodoxy this God is preeminently a triune God. The Father, Son and Holy Spirit find their being in the fundamental relationship that exists between them. Being created in the image of this (triune) God, relationships are seen to constitute the basis of a spiritual imperative for human beings to live in mutual respect and community with one another. It is this theological basis, rather than the secular humanism of western liberalism or the antitheistic tradition of the French human rights tradition, that inspires the Orthodox commitment to the Universal Declaration of Human Rights and documents. (Harakas, 1982)

Religious freedom is a basic human right and this is needed so that the full accountability of the Christian faith may be acknowledged. People thus need to be fully conscious of the interrelatedness of all human rights, and the rights to religious freedom exist so as to serve the religious community according to the instructions of the Holy Scriptures. It is argued by some that human rights have no universal validity but rather constitute a matter of human intentionality. Human rights is thus an ethical principle to regulate living and the human will in social interactions and can thus serve to facilitate the ultimate desires of Orthodoxy and promote human dignity and freedom as such (Trostyanskiy, 2010). Humanitarianism does not exist in basic Orthodox teachings or in theological texts. There are however numerous synonyms and parallels, such as philanthropy, fraternal love, charity and mercy. Christ's directive to love and serve others is a categorical demand to good conduct for believers (Prodromou \& Symeonides, 2016).

The issue of human rights applies to the relations between individuals and between the individual and the government. When looking at Holy Scripture, Biblical law claims to apply even to the responsibilities of individuals towards themselves and their responsibilities towards God. When reviewing biblical law, it establishes responsibilities for which there cannot be a conforming enforceable right and so the biblical argument on responsibilities fashions a diverse mindfulness. Biblical law is focused on the individual rather than on a court of law or the government (Frech, 2005).

The notion of human rights is very contemporary but it is grounded on ancient philosophical traditions for example it is in Cicero's De officiis as 'ius gentium' (Off. 3.69). The Stoics also had a principle of reason called the logos, which apprises us of the idea of a fundamental right mutual to all people and which characterizes the nature which is shared with both God and man (Lutheran World Federation, 1977). The Holy Bible does not speak to the idea of human rights as such and basically concentrates on the relationship between God and man and life eschatologically speaking.

In Orthodoxy the concept of sacramental communion is important, by which believers take part liturgically in the Eucharist as a aide-memoire of God's grace and philanthropy. This generates the possibility for an understanding of philanthropy as an interpersonal, communal act of sharing and communion with others in a spirit of ethical conduct and love (Prodromou \& Symeonides, 2016) and thus 'modern' Christian theology has identified its important commission to endorse the idea and actualization of basic human rights and fair treatment for all due to humanity being formed in the imago dei. (Schaff \& Wace, 1994). God's grace allows us to return to our original standing as being created in the imago dei (Genesis 1:26-27; Psalms $8: 6$ ). We are all equal in terms of Paul (Galatians $3: 20$ ) and we are all Gods children (Romans $8: 12-17$ ) and need to strive towards theosis or becoming godlike. The mission of the Church encompasses the complex linking and incorporation of personal and social transformation in the imago dei (Yannoulatos, 2003). 
There is an absence of the term "humanitarianism" in Orthodox Christian writings. Nonetheless the Church does focus on people and their ultimate renovation in a community as they strive for theosis. "Holman describes Orthodox humanitarianism as an "ethics of aid," which emphasizes social justice, human rights, civic or kinship obligations, charity, and virtue" (Prodromou \& Symeonides, 2016). For the Orthodox humanitarianism is "...premised on the movement of individuals from isolation to a relational personhood grounded on self-sacrifice. Vaisljevic explains that this transition from isolation to community is rooted in the Christological paradigm of self-sacrifice and the inter-personal reality of God as Trinity" (Prodromou \& Symeonides, 2016). The notion of modern human rights constitute a key topic that interests the Orthodox world as a whole and has produced many deliberations, tensions and arguments.

In Orthodoxy the source and telos of humanitarianism is the Ekklesia or Church. In the Ekklesia, for most worshippers, "being Orthodox" is relatively central and considered to be an vital part of their individual identities. However, "objective" Orthodox teachings, requirements and practices as understood by the Church are not necessarily the same as the "subjective" rules which laypeople hold for themselves so as to sense that one is an upright Orthodox Christian.

The reality is that most of Church members make personal choices among various norms of Church life, holding firmly to what they believe is central for their faith and approaching the rest as desirable but not really crucial. In brief, the personally held "creedal" beliefs in Jesus' resurrection and Jesus' actual presence in Eucharist are perceived by the Orthodox laity as the most fundamental criteria of being a "good Orthodox Christian." Orthodoxy places emphasis on the social and communitarian dimension of human freedom and that the human person remains at the very core of Orthodox anthropology, such a person-centric perspective can certainly contribute to the safeguarding of human rights, so that they are not simply transformed into egoistic and selfcentred individual demands and claims. (Krindatch. 2008)

Yannaras $(1998,2004)$, declares a central discordancy between the real Orthodox alignment and the notion of modern human rights as understood in the West.

The term Ekklesia is used to refer to all those who are obedient to God and who are, in a sense, a universal indicator of God's concern for the whole human race, rather than just for the Jews. The 'people of God' (Laos tou Theou), which previously had referred only to Jews, over time became used to denote all Christians (Sanders, 1987). The idea of the singleness of all of humanity is a dominant teaching in the Orthodox Christian faith. In terms of such faith, St. Basil the Great elucidates that all people are interrelated and that all are brothers and sisters (adelphoi), who come from the one Father who made everything (Vasiliades, 1978).

If we wish to comprehend the role of the church in society, it is imperative to have a clear understanding of the term 'people of God'.

The New Testament, as the primary book of Christian revelation, which was passed down to us by the Apostles, is the primary source of orthodox doctrine. It is the most fundamental basis from which we are able to obtain the inspiration of the Holy Spirit. The church fathers and ecumenical councils were protectors of holy tradition (paradosi). Their main task was to make pronouncements supporting the Holy Scriptures as the inspired word of God. They also sought, by using the Holy Scriptures, to enhance the life of the church. (Nicolaides, 2010)

As such, they stimulated a wider interpretation of Scripture and promoted church doctrine based on scriptural truth (Patrologiae Graecae [PG] 32:188). Apart from the Holy Scriptures, Holy Tradition and the teachings of the Early Church Fathers are other authoritative sources which authorise us to interpret the Scriptures. Such tradition enables Christian truths to be kept intact. Holy Tradition permits the development of the canons of the Church and its dogma 
from the Holy Scriptures. St. Basil the Great stated that oral tradition and written Scripture are equivalent to each other, as far as piety is concerned and, consequently, both are imperative for a richer understanding and for living a life that is dominated by the revelatory truth of Jesus Christ. The ideal of Orthodox anthropology is specifically the unrestricted and non-coercive self-transcendence when humans abandon their individual rights in order to assist their neighbours out of a spirit of agape (Bartholomaios, 2017).

Such a phenomenon does not diminish the importance of Holy Scripture. In fact, Holy Scripture is always referred to in Holy Tradition. Consequently, the orthodox faith advocates that all church teachings are contained within Holy Scripture (Androutsos, 1975). The New Testament, as Apostolic teaching, is the fundamental source of Holy Tradition. The church seeks to preserve Holy Tradition as part of the life of the church which 'embraces the truth of the New Testament' (Papadopoulos, 1964). Such a basis must be understood, as we seek to ascertain who the Laos tou Theou are. As orthodox dogmas are acknowledged as divinely revealed truths, they possess total divine authority and are, therefore, considered to be expressions of the consciousness of the church. The pleroma (the fullness of the church) is the conveyor of the dogmas of orthodoxy, as it is inspired by the Holy Spirit through a number of ecumenical councils (Karmiris, 1965). The Orthodox Church repudiates those dogmatic traditions which cannot be related to the Apostles (Berger, 2003), regarding these as false witness. All books of Holy Scripture, both the Old and New Testament, are Theopnefsta (inspired) by the action of the Holy Spirit and must be understood in their general meaning and interpretation and not merely in terms of the words used. The concept 'people of God' is largely based on a number of different biblical preconceptions and premises (Vassiliades, 1988), starting with the idea that God created human beings according to biblical presuppositions and a patristic interpretation of ecclesiology, in His own likeness and image (Papademetriou, 2005). When the Word of God (Logos) appeared, he established a new bond with God's people, which came to include, in the New Covenant, all races and all persons in need of fair and equal treatment (Papademetriou, 2005). Israel, the church of God (Ekklesia tou Theou), is also an eschatological community, which exists in order to gather all peoples and nations under the rule of God, in recognition of Jesus Christ as the Lord of all and our Messiah (Dahl, 1957; Meyendorff, 1987, 2003).

As church members, of one and the same body, the 'people of God' are united with one another and with the divine head of the body, by means of divine grace, which is apparent in their new life in Jesus Christ. It is by means of such grace that they live a new existence, which is spent in unceasing communion (koinonia) with the triune Godhead. "In such a way, they become 'a chosen race, a royal priesthood, a holy nation' (1 Peter 2:9). The identity of the 'people of God' as the elect, or as those who are called by God, is made manifest in the koinonia (fellowship) which they share with Jesus Christ" (Nicolaides, 2010). The Ekklesia church, as that of the 'people of God', continues to offer protection and to strives to perpetuate the faith of the one true God in the world and believers are called to partake in holy communion as an expression of this fact (McKenna, 1975) so as to experience the uncreated light of God and His divine energies (Kilmartin, 1982). Christ is the head and the body, with the church being the Laos tou Theou (Florovsky, 1963). The 'people of God' are the custodians of all truth, including Christian doctrine. The guardian of religion is the very body of the church, the Ekklesia, which consists of the people (Laos).

The term 'people of God', in terms of the Orthodox Church, thus refers to those members of the body of Christ who believe and who will come to believe, in the pleroma (fullness) of the church, comprising the new Israel of God, the 'saints', the 'elect', the 'chosen race', and the 'royal priesthood' (Afanasiev,1967). The church is 'God's holy people', who consist of those baptised who partake in God's Eucharistic communion (Karmiris, 1965, 1973; Nicolaides, 2010). The Laos tou Theou, in either the Old Testament or the New Testament, are all those who have placed their faith in God to save them and who treat others in a spirit of love. The Old Testament 'people of God' trusted in the coming Messiah, whereas the New Testament 
'people of God' put their trust in the Saviour who has come to free us from our spiritual bondage.

In the Orthodox paradosi (tradition), all of humanity is one in the sight of God. St Basil the Great stated that all humans, who are related to one another, are all adelphoi (brothers and sisters) who are given life by God the Creator (Vasiliades, 1978).

The Orthodox view of the Church is not one that restricts humanitarian support to only an elect group within the confines of the Church, but it rather envisages a cosmic Church, which embraces all of creation. "The potential for humanitarian work, therefore, is embedded in every person; consequently, undertaking and participating in humanitarian efforts helps to transform actor and recipient into humanitarian beings and into the fullness of their potential as persons" (Prodromou \& Symeonides, 2016). We are equal according to Galatians 3:20 and possess freedom (Galatians 5:1). In original Greek, фı৯ávӨpono (philanthropos) is explicitly used to designate God's care for the world and if we are created in His image, then we ought to strive to do the same.

Orthodox Christianity hardly ever refers to "humanitarianism" when deliberating its efforts to assuage misery in the world but it is 'full of love for humanity' in its praxis. Orthodox Christians for example, agree significantly about the justification for human rights advocacy, the content of that advocacy, and its status for the mission of the church as God's Ekklesia. Human rights is an abstruse topic, and it is subject to varied individual opinions, historical precedent set by Church teachings, and to situational ethics, but one thing is needed, and that is to understand the God is love and we are in like image and thus need to exhibit love towards all fellow human beings. In reality our solitary right is that of perpetual damnation because of the corrupted nature of humanity. Most of the rights acknowledged by the lifestyle God intended are not universal rights and not all may have the prospect of partaking. But there are circumstances that God has intended for our advantage such as marriage and a family (Genesis 2:24; Psalm 127:5), the prospect of working (2 Thessalonians 3:10) and the notion of group identity (Numbers 33:54). If we transgress the will of God, we are likely to lose all our 'rights'. God's justice exists in His word, for example, we have a right not to be barred from entering a country that is safe when threatened (Leviticus 19:34). This is a rather interesting point in the current world where millions seek to locate elsewhere due to civil strife or wars. We have numerous others Biblical rights as well (see inter-alia, examples at (Exodus 20:12-16, 21:16; 22:2-3; Proverbs 16:11; Deuteronomy 6:7; 14:29; 24:17; 22:25-27; Matthew 5:22; 18:22; John 2:1112). Such rights are endangered by specific sins we may commit. Justice is an absolute, and God means that all and sundry receive it (Isaiah 30:18). As Orthodox believers, we are to emulate Jesus Our Lord and extend mercy to all. Saint Athanasius says, "God became man so that man can become like God." In their day-to-day lives, Orthodox believers understand this through the Holy Eucharist; and Holy Communion, as they enter into intimacy with God and one another, and become collective beings (Kharlamov, 2011).

\section{Conclusion}

Viewed Biblically, no 'right' exists, only what God envisioned for us to have such as a Christian lifestyle of people in the Imago Dei and righteousness for all. Orthodoxy should more openly encourage a cogent dialogue in which individuals with diverse conceptions of what is important in life and in relating to others fully comprehend the need to promote human rights in daily Iving. Orthodoxy teaches that human rights are firmly grounded in the transcendent reality of God and His divine will. People have rights not because they are part of the natural order, but since they are totally loved by a gracious God. When God is met in the God-man Jesus Christ man gets to completely realize his dignity and the dignity of all others who he must love as his neighbours (Matthew 5:43-48) according to the 'golden rule' of life.

In theological terms it is evident that Orthodox humanitarianism is a display of the idea of and involvement of the Ekklesia in the world. "Resolutely grounded in the Church's Christological and Trinitarian doctrines, Orthodox humanitarianism represents an expression of sacramental 
and communal existence. In this regard, Orthodox humanitarianism is simultaneously inward and outward looking in its mission, but is consistently universalist in terms of its focus on the recipients of humanitarianism. By assisting all people - including those beyond the formal faith community of the Ekklesia-Orthodox humanitarianism reflects the salvific mission of the Church" (Prodromou \& Symeonides, 2016). Orthodoxy bases its notion of human rights on the human dignity of everyone as a 'child of God'. Orthodoxy endorses the Universal Declaration of Human Rights because it places the notion of care for others and their dignity, as focus. Orthodox religious traditions and the teachings of the Early Church Fathers and of course Holy Scripture and Holy Tradition do offer us the underpinning on which human rights should be viewed - in a spirit of love.

The various early texts in Christianity, generally provide a moral code detailing the duties and responsibilities of people towards others. All faiths that constitute society should be advocating human rights and allow their devotees to contribute to a caring societal culture and solid ethical public and private life. God has given people dignity and consequently calls all to accept the responsibility of protecting the human rights of others. Christ's gift to all people is the richness of life (John 10:10). When interrogating the anthropology of the Church what is required by all is a Christocentric focus to life.

Ethics as a positive way of life is therefore necessary to add to human rights that stand for a man or woman's right to be the person he or she is created to be. That God-given life is therefore, predicated on ethics and humanitarianism, a basic nature of God imparted to man, but almost 'deformed through disobedience' (resulting from sin) and apostasy.

The two (ethics and human right) can appropriately shape an acceptable way of life once there is the determination by individuals, society, the economy and also in an international dimension to uphold the virtues in these concepts on an ongoing basis.

\section{References}

Afanasiev, N. N. (1967). The Canons of the Church: Changeable or Unchangable?, St Vladimir's Seminary Quarterly, 11(2), 54-68.

Androutsos, C. (1975). Dogmatics, Alpha Press: Athens.

Baker, R. C. (2014). An Examination of the Ethical Discourse of the US Public Accounting Profession from a Foucaultian Perspective. Journal of Accounting \& Organizational Change, 10(2), 216-228.

Barnett, M. \& Stein, J.G. (2012). Introduction. In Sacred Faith and Humanitarianism, edited by M. Barnett and J. G. Stein. New York: Oxford University Press, 3-36.

Bartholomaios I. Ökumenischer Patriarch. (2017). Orthodoxie und Menschenrechte. Evangelische Verantwortung, 9(10), 3-8.

Berger, P. (2003). Orthodoxy and Pluralistic Challenge, in The Orthodox Parish in America, ed. Vrame A., Brookline, Massachusetts, Holy Orthodox Press, pp.33-43

Callahan, D., \& Bok, S. (2012). Ethics Teaching in Higher Education. The Hastings Center Series in Ethics. New York.

Carletta, D.M. (2016). Christian Human Rights by Samuel Moyn. Human Rights Review, 17, 511-513. Available online at https://doi.org/10.1007/s12142-016-0433-3

Dahl, N.A. (1957). The People of God, The Ecumenical Review, (October 1956 - September 1957), n.p. 
de Sousa Santos, B. (2015). If God were a Human Rights Activist. Stanford: Stanford University Press, 1-2.

Diamantopoulou, E.-A. \& Christians, L.-L. (Eds.). (2018). Orthodox Christianity and human rights in Europe: A dialogue between theological paradigms and socio-legal pragmatics. Bruxelles: Peter Lang.

Duska, R., Duska, B. S. \& Ragatz, J. (2011). Accounting Ethics. In W. M. Hoffman \& R. E. Frederick, (Eds.) (2nd Edn). Oxford, UK: John Wiley \& Sons Ltd. Publications.

Elwell, W. A. (1984). Evangelical Dictionary of Theology. Grand Rapids, Michigan: Baker Book House.

Florovsky, G. (1963). Worship and everyday life: An Eastern Orthodox view, Studia Patristica 2.

Frech, S. \& Haspel, M. (eds.). (2005). Menschenrechte, Schwalbach: Wochenschau Verlag. Institute for Human Rights and Business. (2020). Top 10 Business \& Human Rights Issues. Available online at https://www.ihrb.org/library/top-10/top-ten-issues-in-2020

Hall, J. A. (2011). Accounting Information Systems, (7th Edn, pp. 1-801). South-Western Cengage Learning.

Harakas, S.S. (1982). Human Rights: An Eastern Orthodox Perspective, in 19:3 Journal of Ecumenical Studies, 18, 21 (Summer 1982).

Kharlamov, V. ed. (2011). Theosis: Deification in Christian Theology, Vol. 2. Eugene, OR: Pickwick.

Karmiris, J. (1965). Dogmatic and symbolic monuments of the Orthodox Catholic Church, vol. 2, n.p.

Karmiris, J. (1973). A Synopsis of the Dogmatic Theology of the Orthodox Catholic Church. Trans. George Dimopoulos. Scranton: Christian Orthodox Edition, 1973.

Kaufman, A. (2018). Rawls's Egalitarianism, Cambridge: Cambridge University Press.

Kilmartin, E. J. (1982). The Active Role of Christ and the Spirit in the Divine Liturgy, Diakonia 17(2), 95-108.

Krindatch, A. (2008). The Orthodox Church Today, A National Study of Parishioners and the Realities of Orthodox Parish Life in the USA, Patriarch Athenagoras Orthodox Institute, Berkeley: California.

Lovin, R. W. (1989). Perry, Naturalism, and Religion in Public. Law Review, 63, Tulane.

Lutheran World Federation (ed.). (1977). Theological Perspectives on Human Rights, Geneva.

McKenna, J. H. (1975). Eucharist and the Holy Spirit: The Eucharistic Epiclesis in Twentieth Century Theology (1900-1966). Great Wakering: Mayhew-McCrimmon, Ltd.

Meyendorff, P. (1987). Liturgy and Spirituality: I. Eastern Liturgical Theology, in Bernard McGinn, John Meyendorff, and Jean Leclercq (eds.), Christian Spirituality: Origins to the Twelfth Century. New York: The Crossroad Publishing Company.

Meyendorff, P. (2003). Liturgical Life in the Parish: Present and Future Realities, in A. Vrame, ed., The Orthodox Parish in America, Brookline: Holy Cross Orthodox Press.

Mijatović, D. (2020). The impact of COVID-19 on human rights and how to move forward, Commissioner for Human Rights, Council of Europe: Strasbourg. Available online at 
https://www.coe.int/en/web/commissioner/-/the-impact-of-covid-19-on-human-rights-andhow-to-move-forward.

Moltmann, J. (1979). The Liberation of Oppressors, Journal of Theology for Southern Africa, 26, 24-37.

Nicolaides, A. (2010). The Laos tou Theou - an orthodox view of the "people of God", HTS Teologiese Studies/Theological Studies, 66(1), DOI: 10.4102/hts.v66i1.37

Palm, S. (2016). "Reimagining the Human? The role of the churches in building a liberatory human rights culture in South Africa today". Unpublished PhD Dissertation. University of Kwa-Zulu Natal. [Online]. Available: http://researchspace.ukzn.ac.za/handle/10413/13037

Palm, S. (2018). Always reforming? Nurturing a church for human rights in South Africa, Stellenbosch Theological Journal, 4(1). DOI: http://dx.doi.org/10.17570/stj.2018.v4n1.a15

Papademetriou, G.C. (2005). The People of God: An Orthodox perspective, Available online at http://www.goarch.org/ourfaith/ourfaith9285

Papadopoulos, G. (1964). The revelatory nature of the New Testament and Holy Tradition in the Orthodox Church, The Orthodox Ethos - Studies in Orthodoxy, Vol. 1, Patrologiae Graecae 32, n.p.

Peterson, J.B. (1913). The Apostolic Fathers. In Herbermann, Charles (ed.). Catholic Encyclopedia. New York: Robert Appleton Company.

Van Peursem, K. A. \& Julian, A. (2006). Ethics Research: An Accounting Educator's Perspective. Australian Accounting Review, 16(1), 13-29.

Pomazansky, M. (1984). [1973, in Russian], Orthodox Dogmatic Theology (English trans.), Platina CA: Saint Herman of Alaska Brotherhood.

Prodromou, E.H. \& Symeonides, N. (2016). Orthodox Christianity and Humanitarianism: An Introduction to Thought and Practice, Past and Present, The Review of Faith \& International Affairs, 14(1), 1-8. DOI: 10.1080/15570274.2016.1145479

Rawls, J. (1999). A Theory of Justice: Revised Edition, Oxford University Press: Oxford.

Sanders, J.T. (1987). The Jews in Luke-Acts, Fortress Press: Philadelphia.

Scanlon, T.M. (1975). 'Rawls's Theory of Justice,' in Daniels, Reading Rawls, 169-205; originally published in University of Pennsylvania Law Review, 121 (1973), 1020-1069.

Schaff, P. \& H. Wace, eds. (1994). A Select Library of the Christian Church. Nicene and Post-Nicene Fathers. Peabody: Hendrickson.

Sims, R. R. \& Felton, E. L. (2006). Designing and Delivering Business Ethics Teaching and Learning. Journal of Business Ethics, 63(3), 297-312.

Siskova, A. (2008). Russian Orthodox Church Sets Tone On Human Rights. Radio Free Europe / Radio Liberty, June 30, 2008. Available online at https://www.rferl.org/a/Russian_Orthodox_Church_Sets_Tone_Human_Rights/1181014.html

Smith, L. M. (2003). A Fresh Look at Accounting Ethics (or Dr. Smith Goes to Washington). Accounting Horizons, 17(1), 47-49.

Stylianopoulos, T.G. (2008). Scripture and Tradition in the Church. In The Cambridge Companion to Orthodox Christian Theology (eds. M. Cunningham and E. Theokritoff; Cambridge: Cambridge University Press, 21-34 
Svensson, G. \& Wood, G. (2003). The Dynamics of Business Ethics: A Function of Time and Culture - Cases and Models. Management Decision, 41(4), 350-361.

Traer, R. (1988). Religious Communities in the Struggle for Human Rights, Christian Century, September 28, 835.

Trostyanskiy, S. (2010). The Russian Orthodox Church on Human Rights, Philanthropy and Social Compassion in Eastern Orthodox Tradition: Papers of the Sophia Institute Academic Conference, New York: Theotokos Press.

United Nations Human Rights High Commissioner (2017). Human rights in the world - today and tomorrow, Lecture at Columbia University 2017 World Leaders Forum by UN High Commissioner for Human Rights - Zeid Ra'ad Al Hussein. Available online at https://www.ohchr.org/en/NewsEvents/Pages/DisplayNews.aspx?NewsID=22395\&Lan

United Nations (n.d.): Peace Dignity and Equality on a Healthy Planet, New York

Vasiliades, N.P. (1978). Christianismos kai Anthropismos, Saviour Publications, Athens.

Vassiliades, P. (1988). New Testament ecclesiological perspectives on laity, Epistemonike Epeteris 29, n. p.

Yang, S. (2016). Human Rights and the Bible. Faculty Publications - College of Christian Studies, 253. Available online at http://digitalcommons.georgefox.edu/ccs/253

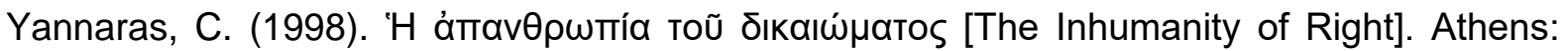
Domos.

Yannaras, C. (2004). Human rights and the Orthodox church. In E. Clapsis (Ed.), The Orthodox Churches in a pluralistic world: An ecumenical conversation (pp. 83-89). Geneva/Brookline, MA: WCC Publications/Holy Cross Orthodox Press.

Yannoulatos, A. (2003). Orthodoxy and human rights. In A. Yannoulatos (Ed.), Facing the world: Orthodox Christian essays on global concerns (pp. 49-78). Geneva: WCC Publications. 